>>>> > STOP ON ARCHIVES

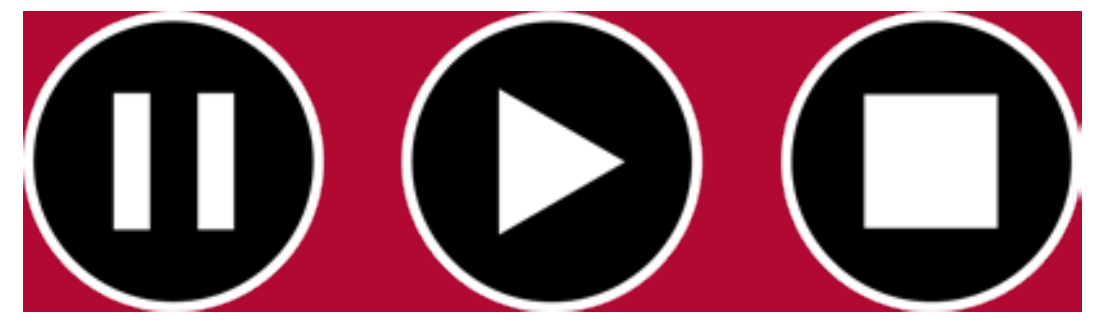

ARRÊT SUR ARCHIVES $<<<<<$ 


\title{
Group Picture of Soviet Assassins: The Trajectory of Stalinist Executioners from the Revolution to the Great Terror
}

\author{
Nikita PETROV \\ Member of the Board \\ International Memorial, Moscow (RU) \\ petrov@memo.ru
}

\begin{abstract}
The article deals with the practice of execution during the period of Soviet political repression. Special attention is paid to the fate of employees of the state security system who served as executioners.

The issue of organising the activities of the "special group" and its place in the structure of the Central apparatus of the Cheka-MGB bodies is discussed. Patterns of career development of executioners and their professional deformation are given.
\end{abstract}

Keywords

Executioners, State security, Vasily Blokhin, political repression in the USSR, Lubyanka.

\section{Résumé}

Cet article est consacré à la pratique des exécutions lors de la période des répressions politiques en URSS. Une attention particulière est accordée à la trajectoire des employés du système de sécurité de l’État qui ont fait office de bourreaux.

Nous abordons la question de l'organisation des activités du « groupe spécial » et de sa place dans la structure de l'appareil central des organes de la Tcheka-MGB. Nous retraçons également l'évolution de la carrière des bourreaux et analysons leur déformation professionnelle.

Mots-clé

Bourreaux, sécurité de l'État, Vassili Blokhine, répressions politiques en URSS, Loubianka.

\section{Аннотация}

В статье рассматривается практика применения расстрелов в период советских политических репрессий. Особое внимание уделено судьбам работников системы госбезопасности, которые выполняли роль палачей. Обсуждается вопрос об организации деятельности “специальной группы” и ее место в структуре центрального аппарата органов ВЧК-МГБ. Приведены закономерности развития карьеры палачей и их профессиональная деформация.

ключевые слова

Палачи, Государственная безопасность, Василий Блохин, политические репрессии в СССР, Лубянка. 


\section{Group Picture of Soviet Assassins: The Trajectory of Stalinist Executioners from the Revolution to the Great Terror}

Revolution opens up black abysses even in such people who could have led quite a trouble-free life otherwise (Солженицын 1993).

The All-Russian Emergency Commission for Combating Counter-Revolution and Sabotage (VChK, or Cheka) under the Council of People's Commissars (Sovnarkom) of the Russian Soviet Republic was established on December 7 (20), 1917. On that day, a Sovnarkom meeting chaired by Lenin took a decision that the dissolved Military Revolutionary Committee (VRK) that had fought the resistance to the soviet regime should be replaced with a new body, the Cheka, which would report to Sovnarkom and be chaired by Felix Dzerzhinskiy. The Commission's mandate was to "suppress and liquidate counter-revolutionary and sabotage activities across Russia" and "send saboteurs and counterrevolutionaries to revolutionary trial and develop measures to combat them." Initially, the Commission was permitted only to conduct pre-trial investigations of cases "insofar as this is required for the suppression." The structure of the Cheka was designed at that time. The Commission had three sections: informational, organisational (to organise combat against counter-revolution across Russia and in the local Chekas), and a unit to combat counter-revolution and sabotage.

In early 1918, the Cheka announced its right to carry out summary executions (shootings). Guided by the Sovnarkom decree "Socialist Homeland is in Danger" that was issued on February 21 of that year, the Izvestiya daily wrote, on behalf of the Cheka, that the Commission "did not see any means of combating the counter-revolutionaries, spies, profiteers, vandals, hooligans, saboteurs and other parasites, other than their pitiless liquidation on the scene of crime..." (Из истории Всероссийской чрезвычайной комиссии, 96).

In the first years of the soviet regime, the reprisals practiced by the Bolsheviks were often public and demonstrative. Not only secret shootings were practiced. In Arkhangelsk, people were shot in daytime and in public; shootings in Nikolaev were accompanied by a brass-band playing (Мельгунов 1990, 144-147). Public executions were approved by Bolshevik leaders. Theoretical evidence was furnished in support of this vivid form of execution. Thus, in the autumn of 1918, Karl Radek wrote in his article "Red Terror" [Красный террор] in Izvestiya: 
Five bourgeois hostages being shot on the ground of a public verdict issued by a plenary meeting of the local Council of Workers', Peasants' and Red Army Deputies, shot in the presence of thousands of workers who approved this act, is a more impressive act of mass terror than the shooting of five hundred people by a decision of the Emergency Commission without the participation of the working-class masses (Радек 1918, 1).

After the civil war ended, secrecy replaced the romantic publicity of terror. The Bolshevik regime focused on how to look respectable and attractive. Everything that was related to such a sensitive issue as executions was carefully concealed and kept off the radar. We are still unaware of any internal resolutions or guidelines issued by the VChK-KGB that regulate the shooting procedure and the procedure for burying the bodies of those who had been put to death. The only exception is a circular issued by the Supreme Tribunal of the All-Russian Central Executive Committee (VTsIK) on October 14, 1922, to all chairmen of tribunals. It says that:

The body of the shot shall not be released to anybody, shall be buried without any formalities and funerary procedures, in all the clothes in which he/she had been shot, at the place of execution or in any other deserted place and in such a way that there would be no trace of a grave, or else this person shall be sent to a morgue (Рогинский 2005, 565).

The shooting procedure and places of burials were a closely guarded secret. The level of secrecy in the executioners' business was so high that very few people among Chekists themselves knew about it. Moreover, from the early 1920 s, information about shooting was not disclosed even to the family of the executed person if a decision about the execution was taken out of court. Even if this information was disclosed, it was always communicated orally and without any official papers (Тепляков 2007, 7-8). When the number of executed people ran up to hundreds of thousands during the Great Terror of 1937-1938, NKVD staff gave the same verbal answer to thousands of people who came to learn about the sentence given to their family members: "ten years without the right of correspondence." The shroud of secrecy surrounded the fate of those who had been arrested and then executed.

\section{"Special group"}

The Cheka initially did not have either special job positions or the idea of having executioners on its staff. It was assumed (and practiced) that the execution of death sentences, if necessary, was to be a duty of every Chekist. In Moscow, "tsar's ministers" were shot in 1918 at the Khodynka Field by Red Army soldiers, and later by members of the Chinese international battalion of the Red Army. Later 
"an institute of professional executioners for hire was established and sometimes it was augmented by part-time workers" (Мельгунов 1990, 146). ${ }^{1}$ In the early 1920 s, there was an established practice whereby the same people began working as executioners at the Cheka's central office in Moscow (Мельгунов 1990, 145). This group consisted of more or less the same people over decades. Unofficially called "a special group," it included mostly the commandant office staff although its staffing principle was to involve Chekists who were capable of shooting people almost every day. This was an informal but very important criterion because not every staff member of the commandant office was capable of doing this.

The participation of some commandant office staff in the shootings could be more or less explained (the office was effectively an armed team that acted as security guards in buildings and facilities that belonged to the VChK-OGPUNKVD-MGB, ${ }^{2}$ and it would be logical to include executions in its mandate). But it is surprising to see Stalin's personal guards in this "special group." Their only duty was to be security guards for Stalin and other high-ranking Kremlin officials but not to take part in shootings.

(See Document 1 at the end of text)

\section{Vasiliy Mikhaylovich Blokhin - Biography of a "reliable" executioner}

The name of Vasiliy Mikhaylovich Blokhin (1894/95-1955), the long-time chief executioner of the Stalinist epoch who took the position of OGPU commandant in 1926, is now familiar to many people. His signature is on numerous documents about the execution of death sentences that are now kept in the Lubyanka archives. People unfamiliar with the nuances of Blokhin's profession as an executioner were shocked and awed when they had a chance to see him in action. Who was the man that acted as a tool of Stalin's arbitrariness? -According to his sketchy autobiography, he was born on January 7, 1895, in Gavrilovka village (Suzdal' district of Vladimir governorate to the family of a middle-income peasant. But his date of birth is given according to the so-called "new style" [Gregorian calendar], while it falls on Christmas Day in December 1894 according to the "old style"

1 In Moscow, regular executions (shootings) from 1918-1919 were carried out in the inner courtyard of the Cheka garage in Varsonofievskiy pereulok. According to available evidence, the procedure was as follows: "The sentenced people strip to underwear, then they were led to the farther end of the yard to the stacks of firewood and shot into the back of the head with revolvers."

2 These abbreviations refer to the Ministry of State Security, which underwent administrative reorganisation during its existence and therefore changed its name several times: All-Russian Extraordinary Commission for Combating Counter-revolution and Sabotage [Всероссийская чрезвычайная комиссия по борьбе с контрреволюцией и саботажем]; All-Union State Political Administration [Объединённое государственное политическое управление]; People's Commissariat for Internal Affairs [Народный комиссариат внутренних дел]; Ministry of State Security [Министерство государственной безопасности]. 
[Julian calendar]. From 1905, he studied and worked as a shepherd, then mason, and also worked on his father's farm. On June 5, 1915, he was enrolled in the $82^{\text {nd }}$ infantry regiment in Vladimir and rose to the rank of junior subaltern. From June 2,1917 , he was senior subaltern of the $218^{\text {th }}$ Gorbatov infantry regiment on the German front. Blokhin was wounded, and recovered in a hospital in Polotsk until December 29, 1917. Then he worked on his father's farm until October 1918, far from any political storms, and on October 25, 1918, he began service as a volunteer in the military commissariat of Yanovskiy, a small administrative peasant division of Suzdal' district. Soon Blokhin made his choice in politics: he joined the communist party in April $1921,{ }^{3}$ and almost at once - on May 25, 1921 - he was appointed to the $62^{\text {nd }}$ battalion of Cheka troops in Stavropol.

His career then developed in the Cheka. He served as an assistant to a platoon commander in the task force at the Cheka Collegium (from November 24, 1921), platoon commander of the same task force (from May 5, 1922), and assistant to the commander of the 61st special-purpose division at the OGPU Collegium (from July 16, 1924). On 22 August 1924, Blokhin was promoted to the position of special-mandate commissar at the Special Division of the OGPU Collegium. His duties included, among other things, execution of death sentences by shooting. Indeed, from the spring of 1925 Blokhin regularly signed documents about the completion of shooting. He might have continued to serve as a rank-and-file executioner but a high-ranking vacancy position unexpectedly became available. On March 3, 1926, Blokhin was appointed acting commandant of the OGPU (in lieu of the temporarily absent Karl Weis). As early as June 1, 1926, he was confirmed in office. His predecessor Karl Weis had an unenviable fate. Executive order No. 131/47 issued by the OGPU on July 5, 1926, and signed by Yagoda, outlined the grounds for his dismissal and sentencing:

On May 31, 1926, a resolution of the OGPU Collegium sentenced VChK/OGPU Commandant Karl Ivanovich Weis to ten years of close confinement on a charge of communicating with the staff of foreign missions who were obvious spies. The established evidence kept in his file portrays Weis as a "completely corrupt person who has lost any understanding of responsibility that is vested in him as a Chekist and a communist, and who has not balked at discrediting the United State Political Administration where he served as a staff member. ${ }^{4}$

Unlike Weis, Blokhin demonstrated proper behaviour, and kept his position of commandant for many years until retirement. On 10 June 1938, his position

3 We do not know much about his motivation to join the communist party. During the Civil War, he served in the Red Army, but did not actively take part in fighting.

4 Центральный архив Федеральной службы безопасности (ЦА ФСБ), ф. 66, оп. 1-а, д. 10. Приказ ОГПУ № $131 / 47$ от 5 июля 1926 года. 
was renamed "head of the commandant's office at the Administrative Executive Department of the NKVD of the USSR." The $10^{\text {th }}$ anniversary of his service as an executioner was recognised in a special executive order (No. 142) issued by the Minister of Internal Affairs Genrikh Yagoda on 27 April 1936. The document said:

In recognition of the irreproachable ten-year-long work of Comrade Blokhin V. M. as the Commandant of OGPU, his continuous development in this position, and successful on-the-job technical studies I hereby order: to award a watch to Vasiliy Mikhaylovich Blokhin, Commander of NKVD of the USSR, State Security Captain. ${ }^{5}$

(See Document 2 at the end of text)

\section{Personal features and biographical backgrounds}

Documents about shootings in the Lubyanka in 1922-1930 were most often signed by Grigoriy Khrustalev, Ivan Ignat'ev, Pëtr Maggo, Andrey Chernov, Aleksey Rogov, Ferdinand Sotnikov, Vasiliy Shigalev, Vasiliy Blokhin, Pëtr Pakaln, Robert Gabalin and Ivan Yusis. ${ }^{6}$ Most of them were staff members of a special section of the OGPU Collegium. This section's duty was to guard the soviet leaders, particularly Stalin himself. That is, they combined the duties of security guards and regular shootings of "enemies of the people." They were recorded as "special-mandate commissars" in the staff lists of the central office of the OGPU: Aleksandr Rogov, Ivan Yusis, Ferdinand Sotnikov, Robert Gabalin, Andrey Chernov, Pëtr Pakaln, and Yakov Rodovanskiy. (Кокурин и Петров 1998, 96). Other executioners served at the commandant's office of OGPU: Blokhin himself, Pëtr Maggo, Ivan Ignat'ev and Vasiliy Shigalev. Later, Ivan Shigalev (Vasiliy Shigalev's brother) joined the "special group," as well as Pëtr Yakovlev (director of the garage that serviced the soviet leaders, then director of the car department at the OGPU), Ivan Antonov, Aleksandr Dmitriev, Aleksandr Emel'yanov, Ernst Mach, Ivan Feldman, Dem'yan Semenikhin, and Aleksey Okunev (he worked at the department of security guards for the leaders of the communist party and soviet government). Okunev was in charge of the burial and cremation of bodies.

A sample of twenty-seven "special group" members who carried out executions in Moscow in 1921-1941 has the following features. Ethnic origin: seventeen Russians and ten Latvians. Social origin: four people were born to working class families; sixteen to peasant families (including seven middle income, five lowincome and four to farm laborers' families); two members originated from families of heavy lifters and one from each of the families of a landowner, tradesperson and

5 Государственный архив Российской Федерации (ГАРФ), ф. 9401, оп. 12, д. 54.

6 Федеральной службы безопасности России (ЦА ФСБ), Ф. 7-ос, оп. 1, д. 163. 
gardener. In terms of joining the Cheka-OGPU, the breakdown is the following: eighteen people came in 1917-1920, seven in 1921-1922, and two after 1923.

A closer look at the executioners' biographical notes shows that they had one thing in common: almost all of them had an elementary level of education, and most of them began employment as workers. Interestingly enough, even those who originated from peasant families moved to towns and cities after the revolution, and proletarianised fairly rapidly. Of course, there were "non-proletarian" cases as well: two people worked as salesmen, two as drivers, one as a gardener and one as a clerk. Thirteen people had served in the tsarist army before the revolution, including three who had the rank of junior subaltern. Eighteen people had served in the Red Army but only two of them were in the Latvian ethnic units (i.e. they had been "Latvian Sharpshooters" before employment in the Cheka). There were case-specific and even unique features, e.g. one of the executioners had served in Denikin's army for a short period during the civil war.

Take, for example, the life stories of two executioners from Leningrad, Mikhail Matveev and Georgiy Alafer. The former came from a middle-income peasant family, moved to town fairly early and was employed as a stoker and later as a porter in a tenement building. The latter was born to the family of a fitter, lost his father early, and worked as a barber for several years before joining the Cheka. Service in the commandant's office of the OGPU resident representative office in Leningrad brought them together (Петров 2017, 8-9).

Executioners led a hard life. Family members seldom saw them, and when they did, they most often saw drunken men who came home after their "night work." It would be surprising if they did not get drunk at this villainous job. Executioners usually gathered together for booze after they had carried out shooting. One of them recalled:

Naturally, we got hog-drunk with vodka. Whatever you say, that was not an easy job. We got so tired we could hardly stand. And we washed ourselves with Cologne water, down to the waist. How could we get rid of the smell of blood and gunpowder otherwise? Even dogs kept away from us and barked from afar - if at all (Сопельняк 1998, 275-276).

No wonder that executioners died young, or went mad. Those who died a natural death included Grigoriy Khrustalev (in October 1930), Ivan Yusis (February 2, 1931), Ivan Ignat'ev (October 15, 1937); Andrey Chernov (in 1940), Pëtr Maggo

7 Since October 1934, Ivan Grigor'evich Ignat'ev served as the commandant at the Military Collegium of the Supreme Court of the USSR. He is the addressee of directives and the signatory of numerous documents about execution of death sentences via shooting that were issued by the Military Collegium in 1937. And dying a natural death in the autumn of 1937 was a lucky gift of fate indeed! 
(in April 1941), Vasiliy Shigalev (in August 1942), his brother Ivan Shigalev (in January 1946), and Aleksey Rogov (in 1947). Many executioners retired and were recognised as unfit for work because of schizophrenia (Aleksandr Emelyanov) or mental disease (Ernst Mach) (Сопельняк 1998, 278). Aleksey Okunev was treated at a mental hospital several times, and finally drank himself to death. ${ }^{8}$

Nor were shooters immune to repressions. Robert Gabalin was arrested for homosexual contacts and sentenced to three years' concentration camp by the Special Commission at OGPU in February 1934. Of course, the badge "Honorary Worker of VChK-OGPU(V)" was taken from this ex-guard of Lenin at once. And some executioners got into Blokhin's hands: they were brought to the shooting area as victims. This is how Grigoriy Golov, Pëtr Pakaln and Ferdinand Sotnikov were shot in 1937. It would be interesting to know what Blokhin and Maggo felt when they shot people who used to be their mates.

(See Document 3 at the end of text)

\section{"Refined" killing and torture methods}

Isay Berg, head of the shooting team of the NKVD Division for Moscow oblast, was also arrested. He made a name for himself because he directly contributed to constructing a gas van in the Moscow NKVD, a vehicle where the convicted people were poisoned by exhaust gas. This saved the Moscow executioners' nerves: the convicted people were put into the gas van in Taganka or Butyrka prisons, their bodies were unloaded in Butovo [Moscow suburban area], -and ho, the work's done! Berg himself told the interrogators that "it would have been impossible to shoot so many people" without this "improvement." At the same time, Berg admitted that "we shot many innocent people, too."10

The shooting methods were changed during the mass executions in 19371938. NKVD staff shot so many people every day that special burial areas were arranged close to the oblast capital cities. The convicted people were often shot right in these areas where they were brought by car. Mikhail Matveev, a man who had executed prisoners from Solovetskiy prison in Sandarmokh, later told investigators [of his case] that the execution was a well-oiled procedure:

Those sentenced to capital punishment were brought by car to a special place, i.e. to a forest, large pits were dug, a prisoner was told to lie with his face down right there,

8 Российский государственный архив социально-политической истории (РГАСПИ), ф.17, оп. 171. д.474, л. 62.

9 Архив Управления ФСБ по Москве и Московской области. Архивно-следственное дело И.Д. Берга, л. 196.

10 Ibid., л. 94. 
in that pit, and then the prisoner was shot point-blank from a revolver (Петров 2017, 7-8).

Torture was the main method of investigation that the NKVD used in those years to obtain the arrested people's confessions. In order to avoid suffering, people signed any kind of confession about taking part in non-existent plots. But they were not spared after they had been sentenced to death. Prisoners were beaten even when there was no sense in doing so. For example, this was practiced in Georgia. Lavrentiy Beria, head of Georgia at that time, told Georgian Chekists to beat those sentenced to death right before the execution: "Knock their teeth in before they kick the bucket” (Реабилитация: как это было, 589). An employee of Georgian NKVD who witnessed the shootings recalled what "horrible episodes unfolded right at the shooting places," NKVD staff "would throw themselves on absolutely helpless people, tied with ropes, like pit bulls and cuff them mercilessly with revolver handles" (Ibid., 589). Georgian Chekists Nikita Krimyan, Aleksandr Khazan, Konstantin Savitskiy, Georgiy Paramonov and Bogdan Kobulov who had taken part in the shootings were convicted only after Stalin's death (Петров 1991, 430-436).

Beating the convicted prisoners before execution was a "trademark" of the NKVD under Ezhov. It was a special feature of de-humanisation and degradation. The Chekists practiced all kinds of things, slipping back into the Dark Ages. For example, NKVD officers in Vologda would hammer the sentenced prisoners on their heads and then decapitate them on a chopping block. ${ }^{11}$ In Novosibirsk oblast, prisoners were strangled with ropes during mass executions by order of the head of the local NKVD department (Тепляков 2007, 58). In Minusinsk (Krasnoyarsk kray), Chekists saved ammunition and finished prisoners off with an iron bar (Тепляков 2007, 73).

In 1937-1938, Blokhin took part in the most high-profile shootings. He gave orders at the execution of Marshal Tukhachevskiy and senior officers who had been sentenced in the same case. Procurator General Vyshinskiy and Chairman Ulrikh of the Military Collegium of the USSR Supreme Court attended the shooting (Реабилитация: как это было, 692). The "iron people's commissar" Ezhov himself honoured the shootings with his presence sometimes. When he was present, the shooting business had certain features of a theatrical performance. In the autumn of 1937: "Before shooting his former mate, Aleksandr Yakovlev, Ezhov put him next to himself to watch the execution." As he took the position next to Ezhov, Yakovlev said to him, "Nikolay Ivanovich! I read in your eyes that

11 ЦА ФСБ, ф.3-ос, оп. 6., д. 1, л. 170. 
you take pity on me." Ezhov did not say anything but was obviously confused and ordered at once to shoot Aleksandr Yakovlev."12

No less memorable was an episode in March 1938, during the execution of Bukharin, Rykov, Yagoda and others who had been sentenced at the "show trial" of the "right-wing Trotskyist bloc." Yagoda was the last to be shot, but before that he and Bukharin were put on chairs and made to look at how other sentenced people were executed. ${ }^{13}$ Ezhov attended this execution, and it was he who had probably invented that refined torture. Before the shooting began, Ezhov told Izrail' Dagin, head of the Kremlin security guards, to beat ex-commissar of internal affairs Yagoda: "Now, let him have it from all of us." At the same time, the execution of Ezhov's drinking partner, Pavel Bulanov, upset Ezhov, and he even ordered them to give Pavel some cognac first. ${ }^{14}$

It is surprising to learn how many former colleagues Blokhin shot colleagues and even bosses on whose words he used to hang. His close ties with the exposed leaders of the NKVD could have cost him his life. His life hung in the balance at least twice but his mastery as an executioner saved him both times. In a way, he was indispensable thanks to his experience and length of service. Ezhov, who began the purges within the NKVD, realised that Blokhin would be useful to him. The wave of arrests was gaining momentum and Blokhin was already reported to have "contacts with the enemies of the people," such as Yagoda, Bulanov and others. Ezhov's "special archive" (documents that the people's commissar did not pass upwards but stored in his safe) included Blokhin's report dated April 3, 1937, addressed to Ezhov himself, with explanations about Blokhin's employment under Yagoda. Ezhov wrote on this report, "Attn.: Comrade Blokhin. All this is nonsense, and I don't see anything bad about it."15 Nothing was held against Blokhin anymore.

\section{Behind Stalin's back}

Stalin, too, highly valued reliable executioners of death sentences. For some reason he was not scared of the fact that people who were used to shooting the back of other people's heads were always behind his own back. His very special (almost careful) treatment of executioners is vividly demonstrated by the following episode from the time when Blokhin was at risk again. In early 1939, when Beria was severely purging the NKVD of Ezhov's people, there was a report saying that

12 РГАСПИ, ф.17, оп. 171, д. 375 , л. 43.

13 Ibid., д. 456, л. 107.

14 Ibid., д. 375, л. 42.

15 ЦА ФСБ, ф. 3-ос., оп. 6, д. 9, л. 49.

CONNEXE 5 | 2019

STOP ON ARCHIVES - ARRÊT SUR ARCHIVES 
commandant Blokhin was too close to Bulanov, ex-secretary of the NKVD, and to Yagoda himself (who had been shot by that time). In those days this was treated as evidence of participation in "conspiratorial plans." Beria drafted an order for the arrest of Blokhin and went to Stalin for approval. To his surprise, approval was denied. Beria said during investigation in 1953, "Stalin did not support me and said that such people should not be put to prison because they do wetwork. He summoned Nikolay Vlasik, chief of his personal guards, and asked him whether Blokhin took part in the execution of sentences, and whether he should be arrested. Vlasik answered that he [Blokhin] did, as well as his deputy A. M. Rakov, and spoke well about Blokhin." ${ }^{16}$ Back in his office, Beria summoned Blokhin and the "special team" to have a talk with them. The people's commissar reported the outcomes of this "disciplinary talk" in a resolution which was never implemented but was kept in the archives:

Top secret. Blokhin and the commandant office senior staff members were summoned, and I communicated to them some information reported about them. They promised to work hard on this and remain loyal to the party and the Soviet power. February 20, 1939. L. Beria. ${ }^{17}$

Stalin never revisited the Blokhin matter.

\section{Sites of execution}

Those sentenced to death were usually brought to Varsonofievskiy pereulok [7-9] where Blokhin and his team awaited them. But sometimes Blokhin had to travel to the victim. This happened in 1940 when Robert Eykhe, former Politburo candidate who had been sentenced to capital punishment, was to be taken from Sukhanovskaya prison to be shot. Right before being transported to be shot, he had been severely beaten in Beria's office in Sukhanovskaya prison:

Eykhe lost an eye which had been gouged out. After the beating, when Beria saw that he could not wring a confession of espionage out of Eykhe, he ordered them to take Eykhe to be shot. (Реабилитация: как это было, 648).

On February 6, 1940, Blokhin had the honor of shooting people's commissar Ezhov himself. Chief Military Prosecutor Nikolay Afanasiev who was present during the shooting of Ezhov described Blokhin's workplace in Varsonofievskiy pereulok where executions were carried out. A thick-walled building was at the back of the yard. Sentences were carried out in "a large room with a sloping cement floor. The farther wall was made of logs, and there were water hosepipes in it. Executions were carried out at this log wall” (Ушаков и Стукалов 2016, 75).

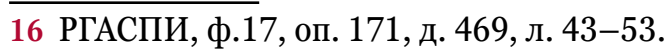

17 Ibid.

CONNEXE 5 | 2019

STOP ON ARCHIVES - ARRÊT SUR ARCHIVES 


\section{Mortal perpetrators}

Blokhin's bosses valued him. He had the rank of state security captain in 1935 and was already a major general a decade later, in 1945. He was lavishly awarded with orders and was given a Pobeda car. By various estimates, Blokhin personally shot at least 10,000 to 15,000 people during his service in the Lubyanka (Петров 2016, 129-155). Blokhin was dismissed right after Stalin's death when Beria regained his position as head of the state security service. With 36 years in the army and security service, he received a pension of 3,150 rubles. However, after Blokhin had been stripped of his rank of general on November 23, 1954, he no longer received pension payments from the KGB. According to a medical report, Blokhin had Stage 3 hypertension and died on February 3, 1955, of myocardial infarction. ${ }^{18}$ Witnesses recall that many people attended Blokhin's funeral. All of them were his colleagues judging by their look and dress. They did not wear military uniform but somehow looked very much like each other, all in black, and their faces made people instinctively uneasy and afraid for some reason. ${ }^{19}$ Ironically, Blokhin was buried in the same cemetery where most of his victims' ashes had been laid, i.e. the Donskoy Cemetery.

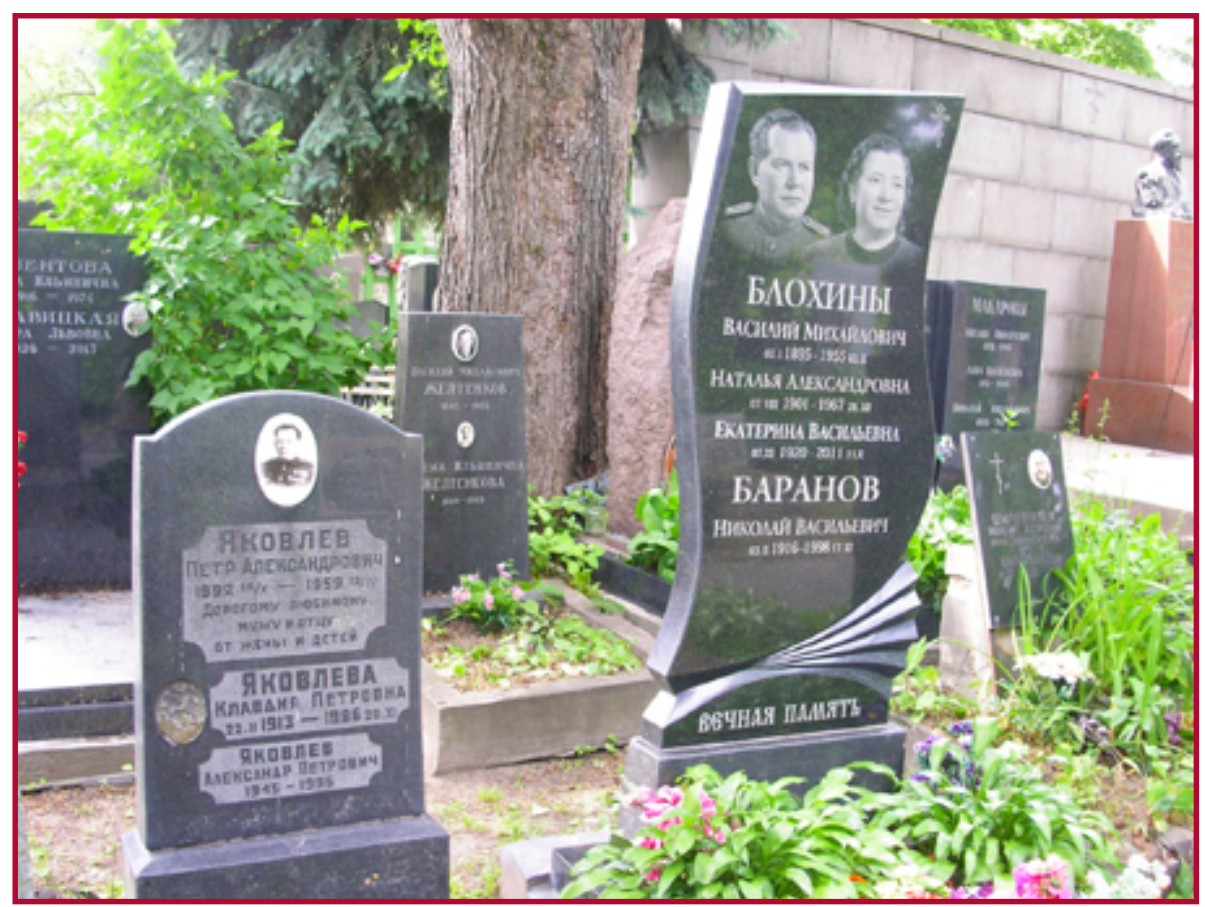

Picture 1

Tombstones of Vasiliy Blokhin and his associate Pëtr Yakovlev from the "special group" at Moscow's Donskoy Cemetery (C) Nikita Petrov

18 Архив УФСБ по Москве и Московской области. Пенсионное дело В.М. Блохина. 19 Discussion with Vladimir Il'ich Il'yushenko. February 2, 2015. 
The bodies of the shot victims were cremated right there and the ashes were put in large pits, but a new beautiful gravestone with Blokhin's portrait was erected on his grave several years ago. He is remembered!

The untimely death of the Shigalev brothers was mentioned above. But two other members of the "special group" did not live too long either. Aleksandr Emel'yanov and Aleksandr Dmitriev died in 1953, and Ivan Feldman followed them a year later, in March 1954. Pëtr Yakovlev died in April 1959 and was buried next to his boss, Blokhin, in the Donskoy Cemetery, while Aleksey Okunev died in 1966. Ivan Antonov and Dem'yan Semenikhin were long-lived: both died in August of 1975.

\section{Friends in ordinary life}

Executioners of death sentences were brought together not by their particularly secret job alone. They stuck together in everyday life as well. Antonov, Blokhin, Semenikhin and Vasiliy Shigalev lived in the same block of flats in Moscow, 3a Bolshaya Komsomol'skaya Str., and Okunev's apartment was in \#5 in the same street. ${ }^{20}$ This was probably not because they wanted it so but because this was how the NKVD provided residential apartments to its employees. But sill, there was certain rationale in this: it would be better if they kept an eye on each other. Ivan Antonov and Dem'yan Semenikhin who died in August 1975 were friends. Semenikhin often visited Antonov, and they both went to work. Antonov and his family (wife and daughter) lived in two sparsely furnished rooms in a multi-family apartment. As his neighbours recalled, he was a reticent person who never spoke about his job or politics and only talked about everyday routine things. In fact, he was a neighbour like any other person, quite an ordinary individual, as Antonov's neighbour states in a conversation with the author. ${ }^{21}$ But there was one detail that struck his neighbours: Antonov was often brought from his workplace in the early morning hours, dragged into his room drunk as a skunk, with huge bouquets of flowers. Having slept it off, Antonov would keep washing his red-haired arms and hands with lots of soap. He would scrub and scrub them, as if he tried to wash something off his hands. The leitmotif is almost classical: he, a guide to the kingdom of the dead, would wash himself clean when he came back to life. It would be interesting to know whether his family ever wondered why flowers had been brought home with him, and where from. It was some sort of decadence with

20 He moved into the apartment of Timofey Prokhorov who had the rank of a major in the security service and was ex-director of the inspectorate of NKVD's Chief Directorate of Highways. Prokhorov was arrested in November 1937.

21 Stated by Vladimir Il'ich Il'yushenko, Antonov's neighbor, in a conversation with the author on February 2, 2015. 
a touch of graveyard atmosphere. A dead drunk person would be brought in, with heaps of flowers, as if every time it was he himself, a person who had shot his own soul, was buried. But perhaps things were more prosaic, and the smell of flowers that could be taken for free from the Donskoy cemetery was to mask the faint smell of blood, gunpowder and decay.



Picture 2

Dem'yan Semenikhin

(Photo of party-membership card. Russian State Archives of Social and Political History).

\section{Witnesses of Stalinism}

After Beria had been arrested, the Prosecutor's Office that took up his case asked questions of the "special group" members. This was because these very people worked during the final stage of Stalin's arbitrary rule and consummated it with the murder of wrongly convicted people. Blokhin was interrogated. Dem'yan Semenikhin was one of those who were of particular interest for investigators. He took part in a summary execution in Kuybyshev City on the ground of Directive No. 2756/b (dated October 18, 1941) that had been addressed to Semenikhin and signed by Beria himself (Дело Берия, 170, 339, 340). This directive ordered Semenikhin to go to Kuybyshev and shoot a group of twenty-five prisoners. The group included Beria's long-standing enemy Mikhail Kedrov who had been acquitted by court. But it was very important for Beria to do away with Kedrov by way of settling old scores with him. Only twenty persons from this group were kept in the Kuybyshev prison, and five people had been shot in Saratov (Ibid., 668). The completion report was signed by Leonid Bashtakov and Semenikhin, as well as by Boris Rodos (deputy head of the NKVD investigative office) (Ibid., 647). It looked like Semenikhin was to be prosecuted to the fullest extent of the law for the shooting of the innocent people and drawing up documents retroactively. But no, the prosecutors followed a different logic: in their view, Semenikhin was not guilty because he had carried out orders. Still, an investigation that was carried out in the 1950s to explore the crimes committed by Beria and his predecessors in 
NKVD did highlight both the mechanism of reprisals and the sinister role of the Donskoy Cemetery crematorium in concealing the outcome of the "jobs" done by Blokhin's "special group."

\section{Aid of the "Special Group" - A "White" colonel joins the team}

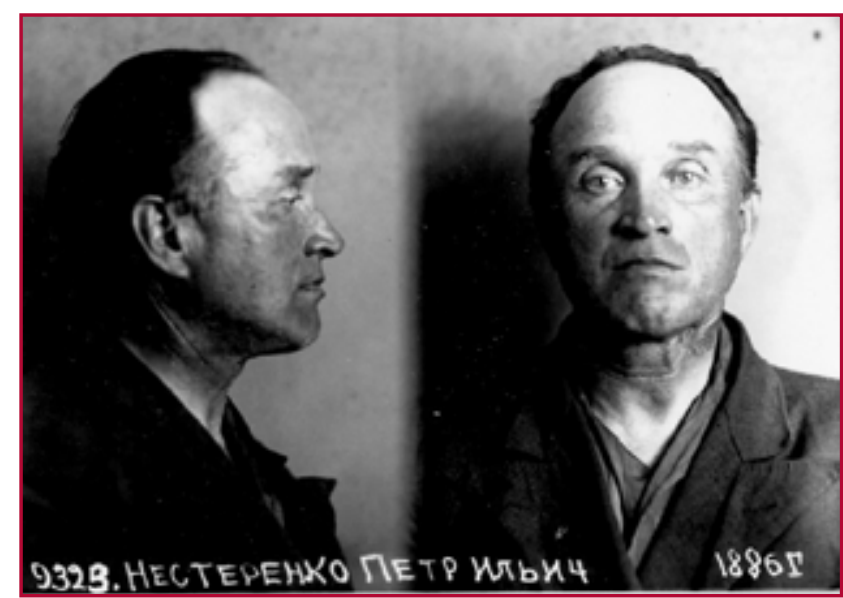

Picture 3 - Pëtr Nesterenko

(Photo from investigation case file. Central Archive of the FSB)

Pëtr Nesterenko, director of the Donskoy Cemetery crematorium, lived in a detached house nearby. He knew a lot, and he saw a lot. He received 200 rubles additionally for his duty to burn the bodies of executed people. Nesterenko can be justifiably treated as an aide of the "special group," almost a member. But he never was, and could not be, a Chekist. He had an interesting biography. Nesterenko was born in 1884 to a family of small gentry. He served in the army and graduated from an infantry school and the Military Aeronautical School (Головкова 2013, 47). He fought in the White Army during the civil war -with the rank of a colonel in Denikin's army. Nesterenko emigrated from Russia, resided in Serbia and Bulgaria, and then moved to Paris where he took an interest in the technical aspects of the cremation process (Рогинский 2005, 572). He went to Berlin to learn this business. A decision to return to the USSR made him an easy prey of the OGPU's foreign intelligence staff. Having served as a secret informer, he was allowed to return to Moscow in 1926 and put his expertise to practical use (Головкова 2013, 48-49). He was appointed the director of the crematorium at the Donskoy Cemetery right after it became operational.

When the first crematorium opened in Moscow, the press was enthusiastic about it and described it as a hygienic facility that put an end to age-long backwardness:

Fire, incinerating fire! This modern temple, this fiery cemetery honours you... The crematorium is a gaping hole in the Chinese wall of people's ignorance and superstitions that God-bothers of all religions used for speculation (Маллори, 1927, 18). 
The press reported the crematorium prices: twenty rubles for cremating adults, ten rubles for children. Although the announced capacity of the crematorium was up to twenty bodies a day, the workload was very high, and "working hours sometimes extended until 10:00 pm instead of 5:00 pm.” (Маллори 1927, 18). What the press did not write about was that a working day was followed by a fullfledged "working night" when the "special group" brought the bodies of executed people to the Donskoy crematorium and had them cremated. The propaganda and popularisation of the new form of burial was massive. Guided tours were arranged to the crematorium, but certainly in daytime only (Головкова 2013, 51). The night job was out of public view. This business ran more or less smoothly until the mid-1930s. Then the "real job" began, i.e. the shooting fever and crunch time. Increasingly more bodies of the executed were brought to the crematorium. Nesterenko was puzzled one day.

In August 1936, Grigoriy Golov and Sergey Zubkin, employee of the Archives and Records Management Section, came to him and asked for the ashes of the executed Grigoriy Zinov'ev and Lev Kamenev. Nesterenko could only guess what they needed their ashes for. Yet, as requested, he "gave them a bucket with the ashes of the shootees" (Рогинский 2005, 572). The key to this secret was in an object that was unexpectedly found by the detectives who conducted a search in Ezhov's apartment in the Kremlin in April 1939. In a writing table drawer, they found a package containing the bullets with which Zinov'ev, Kamenev and Smirnov had been shot. Every bullet was wrapped in a piece of paper with the name of the executed person on it (Лиханов 2017, 38). But where did they come from? The answer is simple. Having sieved the ashes, one could find the bullets that had killed those close associates of Lenin. The question is: who had saved these bullets, and what for? The suggestion that first comes to mind is that Stalin himself wanted to hold the physical evidence of death of people who had been his closest comrades-in-arms. He might have wanted to gloat revengefully at the disgraceful end of their lives after the trial where they had dragged their names in the mud by maligning themselves. But it is not clear whom Stalin could ask. Although in charge of the August 1936 trial, Ezhov was not the commissar of internal affairs yet, and it would be wrong for him to go to rank-and-file Chekists with this delicate request. Besides, Stalin was away from Moscow in those days. He was on leave in Sochi, and would return to Moscow only in October 1936.

Who, then? It was most likely that Genrikh Yagoda, a romantic who was not immune to sentimentality, had given the command to his subordinates. The question is: whether it was his decision or whether it was Stalin's request, after all? It is not clear but Yagoda might have decided it himself. 
There were days when he regarded the leaders of the revolution with admiration and was full of worship and awe. And now there were just bullets wrapped in paper with the names written on it. This was the first shooting of the leaders of the revolution, and Yagoda had mixed feelings as he felt that he had a hand in History, in its beginning and end. This envelope with bullets inside came down from Yagoda to Ezhov when power changed in the NKVD. But what alarmed Nesterenko most of all was that the bodies of people whom he knew very well were now brought to him for cremation. These were the people who had been his colleagues, his drinking companions, or had talked to him just the day before. In June 1937, the body of the shot Pëtr Pakaln was brought for cremation; Ferdinand Sotnikov and Grigoriy Golov came two months later (in August); then (in March 1939) it was the turn of Sergey Zubkin. It is hard to say what Nesterenko felt when he received their bodies against receipt and was to load them into the furnace. Golov was his friend, they used to pass the time together. It was some sinister and mysterious grimace of Fate. Those of his Chekist acquaintances who had not been shot died a natural death. Ivan Ignat'ev, the commandant of the Military Collegium, was cremated in October 1937; Pëtr Maggo was brought for cremation in late April 1941; and Aleksey Kalinin in early June 1941. Nesterenko knew them all very well -as he did those of the "special group" members who were shot in 1937. But these people died a natural death although they died "in action" (Буяков 2008, 383). ${ }^{22}$ They were brought for cremation not in the down-low way at night but in daytime, surrounded with wreaths and escorted by a "group of comrades" who were not laconic in their funeral oration. Indeed, Maggo and Kalinin were buried not in the Donskoy Cemetery sepulchral wall but in the more prestigious Novodevichy Cemetery. Ignat'ev's funeral urn is in the sepulchral gallery in the crematorium building in the Donskoy Cemetery. This is what happened with many of them: they used to bring their victims' bodies, and now they were taken to their last destination. The loop was complete - and their time was up!

Pëtr Nesterenko himself took the same mournful journey into the whirlwind. On June 23, 1941 he was arrested "for anti-Soviet activities." Indeed, it was merely a pretext! Given his job, it is hard to imagine that he could have told anybody anything, not to speak about plotting anything. The time had come to get rid of the person who had been let in on the sinister secrets of the executioners' business. Nesterenko was shot by a decision of the NKVD's Special Commission. But he was shot in Saratov, not in Moscow, and it happened on September 9, 1942 (Головкова 2013, 206).

22 Pëtr Maggo's personal file says: "Died at the facilities on April 26, 1941." 
His testimony during investigation slightly lifted the veil on the secret of burying the ashes of the executed:

[...] After cremation, I myself buried the ashes of the shot defendants of trials in a specially assigned place in the crematorium yard... Nobody but myself knew and could know about this because I buried them personally right after the cremation, all by myself (Рогинский 2005, 572).

Nesterenko said during interrogations that his closest contacts among NKVD staff were Grigoriy Golov and Aleksey Okunev. Besides them, the NKVD secretary Pavel Bulanov and deputy head of NKVD Archives and Records Management Section Sergey Zubkin attended the cremation” (Рогинский 2005, 572).

\section{The most sinister figure}



Picture 4

Aleksey Okunev

(Photo of party-membership card. Russian State Archive of Social and Political History).

It was Aleksey Okunev who usually transported the bodies to the Donskoy crematorium because this was his responsibility area. He deserves closer attention. Aleksey Okunev was one of the most sinister figures in Blokhin's "special group." He did the legwork for the executioners, and was in charge of burials. Okunev was very professional in covering up his tracks. Only scarce reminiscences are available about him: he was a drunkard, and it was only natural that he found his way to a mental hospital. His photo displays a cold evil-looking face and empty eyes that stare nowhere - they tell us better than anything else who we are looking at. This is a vivid demonstration of a personality deformed by the profession, a person from the Chekist twilight, a resident of basements where the shootings had been carried out, and an expert in the world of cemeteries.

Of course, he belongs to the night life - the time when the "special group" was most active. But there were moments when he travelled into the day life. Okunev was on friendly terms with Vlasik himself, chief of Stalin's guards. Of course, they had common past: in late 1920s, when Vlasik was not yet the chief guard, he worked as a rank-and-file employee in the operations department where Okunev was also on staff. Okunev's ability to arrange leisure-time entertainments for the bosses was particularly appreciated. 
This is how one of Vlasik's former girlfriends, Ivanskaya, described her first meeting with Stalin's omnipotent chief of guards:

As far as I remember, in May 1938, an NKVD officer whom I knew -Okunevintroduced me to Vlasik. I remember that they came to me by car, there was a girl in their company, and we all went to Vlasik's dacha. We did not get to the dacha but decided to have a picnic in a forest clearing. This is how my acquaintanceship with Vlasik began. We dated until 1939 (Логинов 2000, 155).

But even after Ivanskaya got married, Okunev continued to invite her persistently to parties at Vlasik's. According to Ivanskaya, Okunev visited Vlasik "very often" (Логинов 2000, 155). He was a frequent guest at Vlasik's parties.

\section{All roads led to the Cheka}

If one carefully reads the biographies of Stalin's executors, the underlying post-revolutionary patterns and even predetermination would become obvious: all roads led to the Cheka for an active and dynamic teenager. We see life stories of common people. These life stories emanate dreary boredom, and the feeling that Evil is prosaic and commonplace would not leave you. It would have been best for them to remain workers, or do peasant work on their farm, or practice barbering, or serve as doormen... But their epoch ruled otherwise, and so they were caught up and drifted by the revolutionary winds. Many of them were drifted into death.

\section{Bibliographical references}

Буяков, А.М. 2008. Ведомственные награды ОГПУ-НКВД. 1932-1940 г2. Владивосток: Русский остров.

Головкова, Лидия. 2013. Где ты? Москва: Возвращение.

Дело Берия. Приговор обжалованию не подлежит. Документы. 2012. В.Н. Хаустов (сост.). Москва: Международный фонд “Демократия.”

Жирнов, Евгений. 28 октября 1990. “Процедура казни носила омерзительный характер.” Комсомольская правда.

Из истории Всероссийской чрезвычайной комиссии. 1917-1921 г2. Сборник документов. 1958. Москва: Государственное издательство политической литературы.

Кокурин, А.И., и Н.В. Петров. 1998. “ВЧК - ОГПУ: структура, функции, кадры.” Свободная мысль 8: 96.

Лиханов,Дмитрий. 2017. “Николай Ежов:прошу нерепрессировать моих родственников.” Родина 6: 38.

Логинов, В.М. 2000. Тени Сталина: Генерал Власики его соратники. Москва: Современник. Маллори, Д. 1927. “Огненные похороны.” Огонек 50: 18.

Мельгунов, С.П. 1990. Красный террор в России. 1918-1923. Москва: “РUICO”- “Р.S.” 
Петров, Н. 1991. “Суды над работниками НКВД-МГБ.” Звенья. Исторический альманах. Москва: Прогресс, Феникс, Atheneum Вып.1: 430-436.

Петров, Н.В. 2016. Награждены за расстрел. Москва: Международный фонд “Демократия."

Петров, Н.В. 4 августа 2017. “Палачи Сандармоха.” Новая газета: 8-9.

Радек, Карл. 6 сентября 1918. “Красный террор.” Известия 192: 1.

Реабилитация: как это было. Документы Президиума ЦК КПСС и другие материалы. 2003. Артизов, А.Н., Сигачев, Ю.В., Хлопов, В.Г., и И.Н. Шевчук (сост.). Том 2. Москва: Международный фонд “Демократия."

Рогинский, А.Б. 2005. “Послесловие.” Расстрельные списки, Москва 1935-1953. Донское кладбище. Москва: “Звенья.”

Солженицын, Александр. 1993. “Черты двух революций." Новый Мup 12.

Сопельняк, Б. 1998. Смерть в рассрочку. Москва: “Гея.”

Тепляков, А.Г. 2007. Процедура: Исполнения смертных приговоров в 1920-1930-х годах. Москва: Возвращение.

Ушаков, С.Ю., и А.А. Стукалов. 2000. Фронт военных прокуроров. Москва: “Сыновья.” 


\section{Document 1}

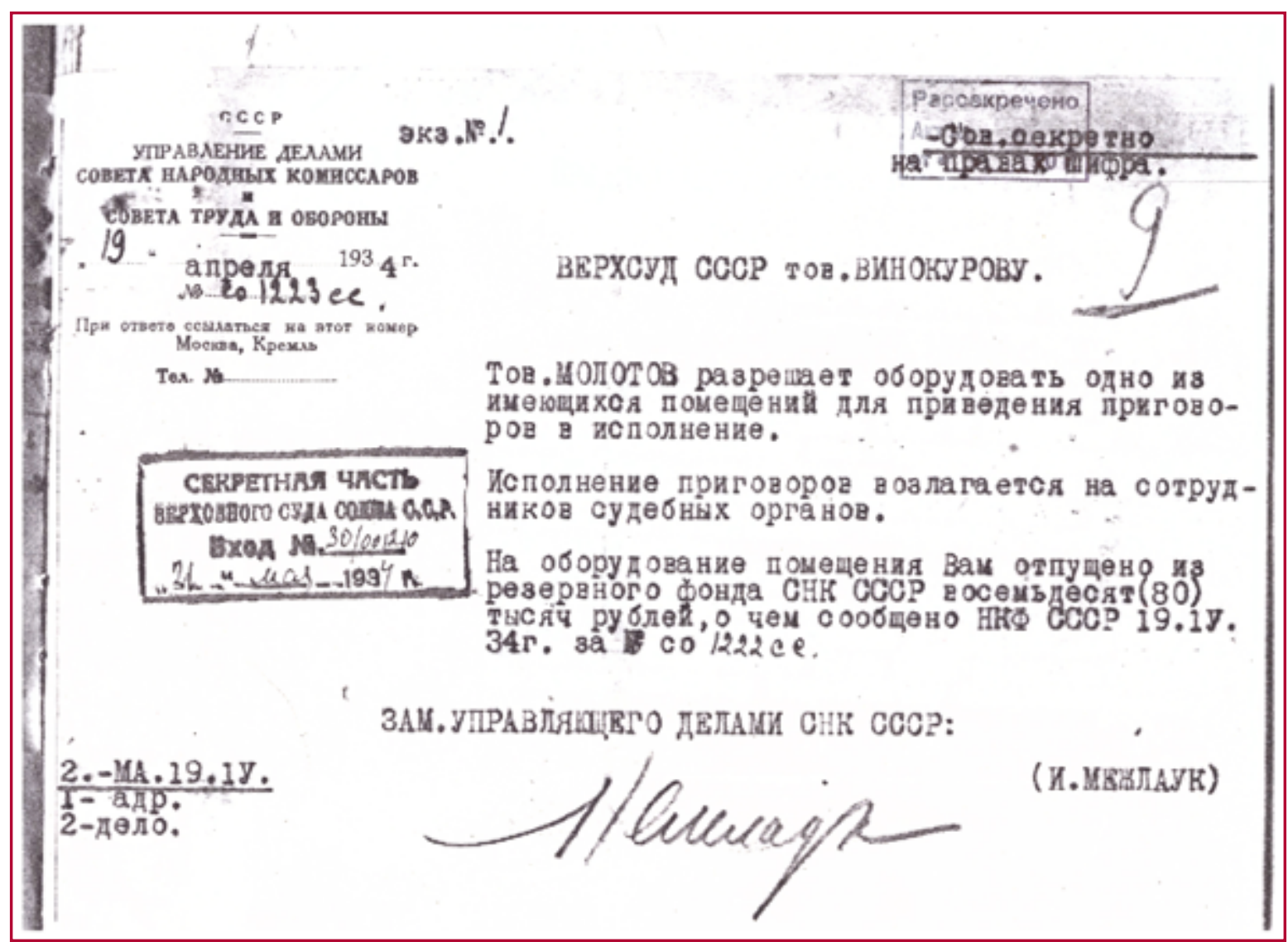

Document 1

Letter from deputy chairman of the Council of People's Commissars of the Soviet Union Ivan Mezhlauk to chairman of the USSR Supreme Court Aleksander Vinokurov giving the permission to equip a room for executions by shooting, 19 April 1934.

(State Archive of the Russian Federation, f. 9474, op. 16. d. 57.1. 9). 


\section{Document 2}



Document 2

Fragment of decree No 252 from the Administrative and Organisational Department of the OGPU announcing the deployment of the Special Unit, 4 November 1925.

(Central Archive of the FSB, f. 66, op. 1, d. 9, 1. 607). 


\section{Document 3}



Document 3

Decree of the OGPU concerning the procedure for the execution of court decisions made by the OGPU Collegium and its Special Board, 6 July 1925.

(Central Archive of the FSB, f. 66, op. 1, d. 141, 1. 122). 